\title{
UNIVERSITYOF
}

FORWARD

THINKING

WESTMINSTER用

WestminsterResearch

http://www.westminster.ac.uk/westminsterresearch

Rethinking Radical Democracy

Tambakaki, P.

This is an author's accepted manuscript of an article published in Contemporary Political Theory, DOI: 10.1057/s41296-018-00284-x, 2018.

The final publication is available at Springer via:

https://dx.doi.org/10.1057/s41296-018-00284-x

The WestminsterResearch online digital archive at the University of Westminster aims to make the research output of the University available to a wider audience. Copyright and Moral Rights remain with the authors and/or copyright owners.

Whilst further distribution of specific materials from within this archive is forbidden, you may freely distribute the URL of WestminsterResearch: ((http://westminsterresearch.wmin.ac.uk/)).

In case of abuse or copyright appearing without permission e-mail repository@westminster.ac.uk 
Paulina Tambakaki

Senior Lecturer in Political Theory

Centre for the Study of Democracy, DPIR

University of Westminster

32-38 Wells Street

London W1T 3UW

Email: tambakp@westminster.ac.uk

Paper Title: Rethinking Radical Democracy

\begin{abstract}
Over the course of three decades, vocabularies of radical democracy have pressed their stamp on democratic thought. Trading on the intuition that there is more to democracy than elections, they have generated critical insights into the important role that practices of pluralisation and critique play in bettering institutional politics. As a result, few would today deny the radical democratic contribution to democratic thought. What many might question, however, is its continuing traction. The paper probes this question, focusing on the nuanced place of democracy in contemporary radical work. It grapples with the difficulties that this poses for radical democrats and it suggests that a way of overcoming these difficulties - that threaten to undermine the coherence of radical democracy - is to rethink and reconstruct the distinctiveness of its vocabulary. The paper attempts such a reconstruction. It develops the idea of the promissory rule of the many and it discusses the ways it rejuvenates broader democratic thought.
\end{abstract}

Keywords: promise, democracy, many, people, popular rule, radical 


\section{Rethinking Radical Democracy}

\section{Introduction}

There is a consensus in the literature that radical democracy designates a distinctive area of contemporary political thought. Set apart by a twin focus on ontology and transformative politics, it foregrounds the manifold ways in which democratic life might be pluralised, energised and reworked. This reworking takes, to be sure, many forms. As the reader familiar with the literature knows, there are many trajectories of radical democracy divided by theoretico-political differences over the type of transformative politics to be aimed for. Despite these differences, however, it has been argued that the pronounced concern with alternatives to the current socio-political order - that is, with possibilities of thinking and acting otherwise - constitutes the common thread among the trajectories of radical democratic thought (Thomassen, 2005, p.116).

The present paper uses this argument as its point of departure. It focuses on democracy - the vector of transformative politics for radical democrats - and it explores the challenges that this gives rise to for radical thought. It suggests that if democracy (practices of openness and participation) no longer emerges as a vehicle for transformation for radical democrats, as the first section shows, then the distinctive contribution of radical democracy to broader democratic thought becomes undermined. But the reverse is also true. When the institutions of contemporary - liberal and institutional - democracy constitute the only vector for radicalisation, then confidence in the transformative politics that radical democrats promise wanes. The paper grapples with this question and the rethink of radical democracy it provokes.

What is of particular interest in this rethink is the intellectual coherence of radical democracy - the contours of its various renditions and the way they might be construed to contribute to democratic theory. This, on the one hand, works to limit the analysis, focusing upon the work of those theories that, inspired by post-structuralism, rework radicalism alongside democracy; however, on the other hand, this same concern inflates the analysis, forcing 
the extrapolation and anticipation of themes that speak to various theories without putting any one of these theories to a systematic treatment. It is the articulation of these two aspects that I propose is incisive for democratic theory. The benefit that comes with this approach is that it allows the reconstruction of radical democracy in a way that recasts anew its contribution to democratic theory.

Two main arguments emerge from this reconstruction. The first is that radical theories find in the notion of the many - and, effectively, in the promissory politics of its rule - an unlikely, yet underexplored, common denominator. This argument departs from the assumption, prominent in the literature, that the ontological turn in contemporary thought is what distinguishes and determines the agenda(s) for radical democracy (Tønder and Thomassen, 2005). It proposes that something more than ontology constitutes a distinctive feature of radical democratic thought. The argument also departs from the priority that the literature gives to political subjectification. It proposes that the subject that subjectifies has a recognisable name: the many.

The second argument that the paper develops is closely related. It suggests that there are advantages to this reconstruction of radical democracy around the promissory politics of the many. If we consider that the main challenge confronting contemporary democracies concerns popular discontent with governing elites and the rejection of all politics styled as normal, then we notice that radical theories tap into this discontent. First, they are astutely attuned to the uneasiness surrounding the neoliberal politics of institutional democracies; second, they anticipate the ensuing loss of popular affect for democracy. In so doing, theories of radical democracy yield critical insights into the ways in which contemporary democracies might be regenerated that it is possible to miss if we evade the need to rethink and reconstruct radical democracy. The last section of the paper explores these insights and it outlines the benefits they bring to a democratic theory that underplays the ways in which promissory politics nurtures democratic attachments. Before this, the next section sets out the grounds for rethinking radical democracy. 


\section{Democracy in Radical Thought}

The aim of this section is to explain why there is a need to rethink radical democracy. It suggests that divisions about the usefulness of democracy as a vector of transformative politics threaten to undermine the intellectual coherence of radical democracy. They also significantly challenge its distinctiveness as a third debate in contemporary democratic theory.

To grasp the seriousness of these challenges, one needs to begin by noting that the distinctiveness of radical democracy as a debate in democratic theory is inseparable from the account of democracy it offers as an open-ended process (Tønder and Thomassen, 2005) . This account is, to be sure, influenced by ontological reflection. ${ }^{1}$ As the literature rightly explains, reflection on being reveals the contingent and contested nature of democratic foundations (Kioupkiolis, 2011; Marchart, 2007) But such reflection does more than this. It gives centre stage to bottom-up participation as the exemplary form of activism that contests closures and ensures openness (see Norval, 2001; Little and Lloyd, 2009; Trend, 1996; Kioupkiolis, 2011; Conway and Singh, 2011). When relations of exclusion become challenged and struggles for equality extend to ever new domains, socio-political practice radicalises and expands ${ }^{2}$ (Laclau and Mouffe, 2001; Chambers, 2004; McClure,1992).

This kind of radicalisation through democracy - that is, through practices that stimulate participation and openness - is what I take to be distinctive of radical democracy as a debate in democratic theory. It is also what I use as the point of departure for reconstructing radical democracy in the ensuing sections. To grasp why this idea of radicalisation through democracy occupies centre stage in my discussion, it is worth reflecting further on its standing in radical thought. For a good part of the literature, democracy, as I have already defined it, functions as a signifier of more equal - inclusive and meaningful relations. Even when this equality does not actualise (as it never does), it is assumed that more democracy - practices that, as we have seen, stimulate participation and openness - will incite change. Democracy thus transpires as 
a vector of transformation for radical democrats in a way that is not always recognised (or questioned) in the literature.

No doubt, the literature has paid much attention to the relation between democratic practice and institutions of representation (Tormey, 2015; Thomassen, 2007). It has also paid attention to vertical and horizontal modes of transformation (Prentoulis and Thomassen, 2013; Kioupkiolis, 2018; Hardt and Negri, 2017; Kioupkiolis and Katsambekis, 2014). But it has not sufficiently reflected on the ways that assumptions of radicalisation through democracy - this common article of faith among radical democrats - weave together and challenge radical democracy. It has, therefore, failed to register how gnawing doubts about such radicalisation threaten to unravel the intellectual coherence of radical democracy as a debate in democratic theory. They take aim at the distinctive contribution of radical democracy in democratic thought - namely, its particular reworking of democracy - and, in so doing, they raise questions that radical democrats have, to my mind, evaded for too long. ${ }^{3}$

Prominent among these questions is the following: Are the categories of openness and participation - or, in other words, democratic practices that stimulate participation and openness - sufficient to radicalise socio-political life, if by radicalisation we understand practices of emptying? Practices of emptying is a term that I borrow from the work of Ernesto Laclau, who insists that the aim of radical democracy is to produce emptiness - and not just assume this as the structural condition of democracy (2005, p.171). Emptying is, in this sense, the kind of operation that inscribes radicalism in the account of democracy that one finds in radical thought. It is also the kind of operation that is increasingly being doubted across various lines of thought. Three sets of doubt are noteworthy.

The first set brings attention to the context of capitalism and the ease with which it co-opts the categories of emptiness, openness, difference and multiplicity - the currency, in other words, of radical democracy. Bruno Bosteels' work is a good case in point here, for he argues that as the capitalist 
market promotes the same themes as that of radical democracy, these can only be used to describe capitalist forces (2011a, pp.63-64). At the same time, Bosteels argues that - when the issue is no longer the totalities of twentieth century totalitarianism, that radical democracy was originally conceived in opposition to - the emphasis on emptying hollows out all emancipatory potential (Bosteels, 2011b, pp.261-262).

This critique must not be misunderstood. The categories of openness and difference are an invaluable resource for all progressive - and not just radical democratic - thought. But they are not the only available resource as the next section shows. They open the way for a reflection that cashes in on the possibilities that such categories hold for transformation - what I later capture with the idea of the promissory rule of the many - without, however, either undermining or exaggerating the critical value of democracy for radical democrats. This is what, in the final analysis, Bosteels' critique brings to the fore, namely, the need to put the transformative potential of such democracy (practices of emptying and opening) under critical scrutiny.

Parts of the literature resist the need for such scrutiny. Laclau and Mouffe's account of radical democracy exemplifies this position. On the back of the assumption that the democratic principles of liberty and equality serve as the horizon that enables social movements to create chains of equivalence that challenge relations of subordination in all areas of social relations; Laclau and Mouffe heavily invest in democracy as a vector for transformation (2001). Mouffe, more recently, insists further on such investment not because she underestimates the effects of capitalism on the category of democratic openness, or even the limits of the liberal hegemony over democracy, but because she suggests that, as a signifier, democracy is still relevant to the struggles of social movements (2018, pp.41-51). In underlying continuity, then, with the argument first developed in Hegemony and Socialist Strategy, Mouffe argues that another articulation between democracy and liberalism and, therefore, a better implementation of liberal democratic principles can yield a different -more socialist, more equal and more democratic hegemony (2018, p.45). 
It is at this point that the second set of doubts comes to the fore - as theories concerned with practices of radical democracy in the Global South forcefully question how transformative another articulation between liberalism and democracy might be. Janet Conway and Jakeet Singh refer to this body of work as 'the alternative tradition of radical democracy rooted in practices of subaltern social movements' (2011, p.689). For this burgeoning literature the problem is that the hegemonic signifier of democracy silences and disqualifies ways of doing politics in contexts other than that of liberal democracy. Therefore, it comes with little radical potential for societies that mobilise different traditions of knowledge.

The perspectival or place-based epistemology 4 that these alternative traditions of radical democracy employ brings into focus practices of reciprocity, inclusion and cooperation (Conway and Singh, 2011, p.702). In other words, it brings into focus the perspective - the suffering, the practices, the imaginaries - of the other, not just her being. This is where in the end the limits of democracy lie, for this second line of thinking: the transformation it promises does not go far enough if the aim is only to (re)produce emptiness within universals such as that of liberal democracy. Liberal democracy must first be displaced - and knowledges become accordingly delinked, as Walter Mignolo proposes (2000; 2009) - for democracy to ensure a meaningful transformation that embraces alternative knowledges and practices as democratic. After all, theorists and activists engaged in practices of subaltern social movements do not altogether dismiss democracy as a vector of transformation. They seek to redescribe or mobilise it as a 'connector' that juxtaposes liberal with alternative renditions of democracy as reciprocity, cooperation and inclusivity (Mignolo 2000, p.742; see also Tully, 2014).

Such redescriptions and mobilisations, nonetheless, point toward a third line of critique. It can be explained as follows: if the transformative potential of democracy that holds together radical democracy as a debate in democratic theory always draws on some articulation with liberalism, then radical democracy might be, in the end, more of a consensus than a debate. Perhaps, it is the political project of one strand of the post-Marxist left? This is 
the point that new theories of communism allude to. By new theories of communism I mean the recent body of work that seeks to revive communism as the most meaningful horizon for a radical politics that aims to foster equality, plurality and popular rule. While there are many strands of such work - divided over what communism precisely designates (an idea or a political project ${ }^{5}$ ); how it is to be achieved (through vertical or horizontal forms of organisation) and how it relates to capitalism (as its inverse or outgrowth ${ }^{6}$ ); they all strongly agree that communism constitutes a radical emancipatory project that captures the 'egalitarian possibility' missing from contemporary democracy (Badiou, 2013, p.46; see also Žižek, 2011, pp.475, 477).

The upshot of this argument is that democracy becomes stripped of all transformative potential - partly because it fails to actualise the equality that these theories use as their point of departure (Dean, 2012); partly because it becomes reduced to the majority procedure that helps the management of the common of communism (Hardt and Negri, 2017). What surfaces, therefore, here is that emptying, the sine qua non of radicalisation through democracy, is again not enough. Some actualisation of equality is necessary. Communism promises such actualisation, for it melds with the egalitarian possibility, and in so doing, it eschews the need for democracy. Or as Dean puts it: [Communism] designates the sovereignty of the people, and not the people as a whole or a unity but the people as the rest of us' (2012, p.69). In the next section I will show how the concern with the people as the rest of us common among radical democrats who stress the need for bottom-up struggles that extend democracy - offers one opening to reconstructing radical democracy in a way that does not abandon democracy. Here suffice to note that calls to divorce aspirations to transformation from democracy are becoming alarmingly popular among strands of the post-1968 left.

What is alarming about such calls is that they offer support to (what increasingly looks like) a consensus among political theorists that democracy - liberal, institutional, representative, radical - fails to deliver for the people it is supposed to serve. While suspicions of (liberal and institutional) democracy are not new among radical democrats, they take on new urgency in the 
context of rising inequalities and an intensification of neoliberal politics. They tap into concerns about how best to challenge such a context and, in so doing, they offer an opportunity to reconstruct radical democracy in a way that makes apparent some of the benefits it brings to broader democratic thought. The underlying intention behind this reconstruction is to change the terms of the radical democratic kinship in a way that attends to the three worries about the transformative potential of democracy without however loosing sight either of the need to retain some references to democracy or to openness. The next section takes a first step to this reconstruction. It develops the idea of the promissory rule of the many and it shows how this helps to conceptually rejuvenate, and thus reassert, radical democracy.

\section{The Promissory Rule of the Many}

The aim of this section is to look for another common denominator among radical democrats other than the idea of radicalisation through democracy that as the previous section showed threatens to silence the distinctive voice of radical democrats within broader democratic thought. If radicalisation through democracy - processes of emptying through practices that stimulate openness and participation - is not enough to inspire transformation outside the context of twentieth century totalitarianism, the confines of liberal democracy and a spirit of confidence in socialist accounts of equality; then is it possible to rethink such radicalisation in a way that mobilises the insights that the categories of openness and participation yield while negotiating the limits of emptying?

The section addresses this question by introducing the concept of the many and canvassing the promissory dimension of their rule. It argues that this promissory dimension, latent in all theories of radical politics, lays the ground for widening the ambit of radical democracy. The crucial point to note here is that the ambit of radical democracy does not widen by forcing various renditions of democracy to fit into one straightjacket. Rather, the point is to show that the political alternative, which all radical theories offer, hovers around the particular idea of the many and the promissory politics of its rule. 
Whether this is still a democratic politics remains at this stage an open question. I engage with this question in the next section. Here suffice to note that the category of the many captures the points of intersection among the various renditions of the political subject that one finds in radical theories ${ }^{7}$ without privileging any one of them. It also bears the imprint of poststructuralist deconstructions of the political subject (Bosteels, 2016, p.20) eschewing the dangers of fixity, uniformity and closure that are hemmed in modernist accounts of the rights-bearing citizen of the state (McClure,1992).

To grasp, then, the specificity of the category of the many, it is worth contrasting my own account with those renditions of the many that immediately spring to the mind of the informed reader. The many is not synonymous with the multitude or the poor who threaten political oligarchies because of their sheer number (see Hardt and Negri, 2012). This is because I am less interested in the distinctive properties of the many (for example, their overpowering number or poverty that will incite transformation) and more in their indistinctiveness (that tallies with democratic processes of emptying). Along similar lines, the category of the many, at least in the way I intend to develop the term here, should not be conflated with the multiple constituencies - the 'militant, cross-regional, pluralist assemblages' - that William Connolly associates with the politics of swarming in his more recent work (2017, p.144). Connolly's account of such assemblages draws attention to their capacity to deliver transformation as they militantly disrupt corporate politics. By contrast, the many that I invoke in my reconstruction of radical democracy shows little evidence of such capacity. For as I intend to argue later in the section, it is the threat that its rule ingrains and poses to a given order that is laden with transformative potential, not the assemblying of the many per se (as Deleuzean influenced approaches to the multitude often propagate). For this reason, the many must also be distanced from the category of the majority prominent in epistemic arguments for democracy (Estlund 2008; Landemore 2012). As I approach it here, the many does not gesture toward decision-making. The category only mobilises the different, the excluded, the other - in other words, the currency of radical democracy - to 
show that the transformation that such radical accounts promise is possible to construct in different terms.

To support this reconstruction, it is useful to note how the focus on processes of subjectification, palpable in all radical theories, prefigures and lays down some markers of the category of the many. Subjectification designates the set of processes by which political subjects form out of the plural and excess materiality of socio-political relations (Rancière, 2011, p.15; Prentoulis and Thomassen, 2013; Woodford, 2017). Radical theories as diverse as those of Jacques Rancière, Hardt and Negri, Ernesto Laclau and Alain Badiou, to name a few, suffuse such processes with the potential to transform the institutions, identities and principles of determinate socio-political orders. While such theorists certainly disagree on how subjects subjectify and what this subjectification achieves (momentary disruption or a break with the existing socio-political order), they all converge in the idea that the political subjects which subjectifying processes constitute are key to triggering sociopolitical transformation. Thus, it is safe to assume that there is an intimate connection between processes of subjectification, which politicise (and inevitably produce) the many, and transformation. This connection is an important first point to notice because it explains why the category of the many opens the way for an alternative account of rule, distinctive of radical theories.

Jodi Dean's recent work, Crowds and Party, is instructive in this respect. It suggests that the collective subject, which processes of subjectification give rise to - the crowd according to Dean - releases an egalitarian force that is capable of 'rupturing' the individual form on which neoliberalism thrives, thereby initiating transformation (Dean, 2016, pp.5, 215). The crowd, explains Dean, 'is those proletarianised under capitalism' (2016, pp.16-21): the disempowered, exploited, impoverished, and excluded from democratic structures who rise to challenge these not from the position of a set identity say ethnically defined - but from their non-position or, perhaps more accurately, from the position of their non-identity. On this ground, Dean's account of the crowd comes very close to Rancière's 'have-nots', whose claim 
to equality disrupts the police order (1999 and 2011, p.37); Badiou's 'inexistent' (2010, pp.9-10); and Laclau's 'plebs' - the underdog in the making (2005).

This suggests that the non-identity of the many constitutes its second noteworthy attribute. Non-identity designates a 'deprived existence', that is, a certain hollowness of economic and political being that nonetheless constitutes in its hollowness some thin basis for collective identification. Nonidentity does not designate any set of fixed or normalised markers, as is the case with common usages of the term identity. It captures the web of deprivations that at once articulates and empties identity. Deprived existence encompasses references to lack and antagonism, that are central in Lacanian influenced accounts of radical theorising, while fostering a generality that is especially useful to the reconstruction of the radical democratic kinship that I undertake in this section.

What is, more precisely, useful is that deprived existence leaves undecidable the question of whether the many politicise because they are impoverished politically - as Hardt and Negri for instance suggest with respect to representative democracy (2012); or economically - as Žižek (2010) argues when he prioritises economic antagonisms. Yet this is an important question to consider when the intention is to reconstruct the common ground among radical theories. Second, and closely related, deprived existence elicits politicisations that might not necessarily aim at reactivating democratic institutions - as Laclau anticipates (2005). It therefore leaves open nuanced questions about democracy and this openness is important for my discussion that intends to defend the signifier of democracy (in the next section). Third, deprived existence prefigures a certain claim to equality that none of the theories concerned with radical emancipatory projects will object to. Shortly, I will return to expand on this point. Here suffice to note that the deprived many offers the basis for a revised account of radical democracy. The remaining of the section probes the ways in which they pledge to rule. 
To grasp the intricacies of such a pledge, it is important to observe that the focus on ruling might rightly appear, at first impression, counter-intuitive. It gestures towards a relation that is difficult to tackle from the perspective of radical theories that agree on the need for openness but disagree on whether a transformative politics breaks with or improves the liberal democratic order. However, if we scratch beneath the rhetoric of transformation, that occupies a central role in treatments of radical theorising in the literature, it is possible to identify a distinctive reflection on the rule of the many - that can be used to strengthen the dialogue with democratic theory. At the heart of this reflection is the idea that the many can rule, even though they fail to do so. The reasons for this failure hinge on, without a doubt, the ontological presuppositions of individual theories and point toward either a necessary feature of the structure or to some temporary obstacle to socio-political actualisation. But this failed rule (if it must be seen as failed) does not in any way undermine the claim that all radical theories retain open the possibility of rule - especially if by rule we understand the process of leading or beginning to take command of politics.

This understanding draws on the polysemic nature of the verb to rule (kratein) and a nuanced distinction already implicit in the term democracy between governing (kybernein) and leading (archein). ${ }^{8}$ Whereas the former verb denotes steering and cannot be easily dissociated from that which is being steered - in this case, the representative institutions that the people steer or are steered by (depending on how one reads such processes); the second verb, archein, means, to lead - in the sense of both 'heading' and 'going before' - and instaurs, as a result, a more flexible relation with institutions. Institutions of representation might rupture as the theories of Hardt and Negri and Badiou propose, but they can also be taken over and controlled by the many as Dean's, Laclau's, and Žižek's accounts of verticality propose. At the same time, the idea of archein (leading) tallies well with the practices of inclusivity and cooperation that radical political practices bring, as we have seen, to the fore. In sum, the underlying point here is this: if we follow the idea of archein (leading), already implicit in the verb to rule, then it is possible to tease out of all radical theories a reflection that calls attention not just to the failed nature of this rule, that I have already stressed; but also, crucially for the 
next step of my argument, to its equal and promissory dimension - for the arche of the many both demands and promises equality.

What is the nature of this equality? To avoid tying equality with a telos that no matter how desirable threatens a degree of closure, some radical theories suggest that equality arises as a demand at the level of the subjectifying process (Rancière, 1999; Laclau, 2005). Whether this demand is met (or not) is irrelevant and it can even be undone. At the same time, most (if not all) radical theories accentuate the inequalities which capitalism harbours and counterpoise these inequalities to the equality that the category of the many announces. Therefore, equality resides in this context in the many and it takes its concrete meaning from the antithesis with the unequal few (who look to their own benefit). It is also noteworthy that for a few theories equality constitutes the very horizon for the emancipatory process, both alleviating and disrupting the current antinomic order (Badiou, 2010; Dean, 2012; Žižek, 2010). Following, then, the consequences of this line of thought, we can say that references to equality stage a promise. The promise is that the many can rule and, in so doing, initiate another order.

The promissory dimension of this order guarantees the open-endedness that one associates with radical theorising; but it does more than this. Understood as a possibility in the now, the promise projects equality - along with the notion of the many with which it is bound- into a tangible force that taps into, yet assuages, anxieties about growing inequality. It does not tether the possibility for equality with that of its actualisation. Therefore, it is not the same as the promise of eventualization ${ }^{9}$ that one finds in the Deleuzeaninfluenced universe of becoming - most evident in Hardt and Negri's work (2009 and 2012). It is also not synonymous with the promise of potentiality found in the Derridean repetition from an open-future (Derrida, 2006; Fritsch, 2002) - as this takes the reconstruction of radical democracy back to the very ideas that I problematise in the first two sections.

In a subtle departure from Derrida's account of promissory politics as the affirmation of a radically open future (2006), the rendition of the promise that I 
want to outline presses the categories of openness and potentiality further. It draws out its threatening and, effectively, destabilising dimension with the aim of accentuating the effects of promissory politics on unequal and exclusive orders. The upshot of this move is that the promissory politics of the many that I discuss here certainly frequents and haunts the present in line with Derrida's account of the promise (2006, p.127). The nature of this haunting is however different. First, it is ontic - not a hauntology (Derrida, 2006, p.202) because I want to posit the promise in the rule of the many. Second, it does not designate a 'gap', an otherness constitutive of being, as it does for Derrida (2006, p.81) but a genuinely threatening possibility. The promissory rule of the many has, as a result, a restraining effect that might be easy to fathom by bringing to mind the freezing reactions that usually arise in situations that inspire extreme fear. Fear, then, not messianic hope - for hospitality and another politics - is what lies behind the type of promise that I want to associate with the rule of the many.

It follows from the above that my understanding of the promise lies in-between discussions of potentiality that insist that politics may happen (again differently) and discussions of actuality that suggest that politics will happen (differently). The first position, which finds its most elaborate expression in Laclau and Mouffe's work, particularly their emphasis on re-activation through counter-hegemonic politics and a left populism, fails to register the limits of contemporary democracy when it comes to tackling socio-economic inequality (2001; Mouffe, 2018; Laclau, 2005). The second position, that is apparent in Bosteel's writings among other work (2011a), fails to appreciate the strengths of contemporary democracy - particularly the threatening dimension of the principle of popular rule apropos of plutocratic politics. I will return to expand on this point in the next section. Here suffice to say that, in a subtle departure from both of the above positions, my account of the promise presses the idea that the many could rule - for it is this 'could' that plants egalitarian politics in the now as a real possibility; and frames this possibility both as a threatening and as a distinctively democratic one. 
The democratic specificity of this possibility nonetheless raises one final crucial question: Why should the promissory rule of the many be tied to democracy? Terms such as 'equality', the 'promise', or the 'many' do not attach to any particular framework and can in principle affix to communism much like the concept of the people, (as Laclau shows, 2005, p.167). To answer this question, that strikes at the heart of the intention to rethink and reassert the idea of a radical democracy, it is prudent that we take a small step back to reflect on the strengths of democracy - or, in other words, why democracy is still worth the candle as a signifier given the mounting animus against it. The next section is tasked with this reflection.

\section{The Democratic Promise}

The previous section concluded by proposing that the promissory rule of the many be repositioned within a democratic framework. By a democratic framework, or simply by democracy, I understand the promise of popular rule - as I defined the promise in the last section. Of primary concern here is the name we give to this promise of rule and how this name affects and is, in turn, affected by the workings of institutional politics. Wendy Brown's work, Undoing the Demos, helps us to grapple with this concern, because she draws a useful distinction between the conditions for democracy on the one hand, which institutions foster and neoliberal governmentality erodes; and the ideal of democracy on the other hand - that inspires social mobility, equality and a rich humanism (2015, pp.178-200). The word 'inspire' is key here, because Brown does not argue that the principle of popular rule secures true freedom and equality. She only argues that this allows for articulations of a variety of lofty principles (such as that of equality), which ensure that the pursuit of these principles remains possible for the majority of citizens of democratic regimes (2015, p.186). It is these articulations that social movements exploit to challenge stratified social orders (2015, p.206). And it is these same articulations that neoliberal governmentality threatens with the spread of economisation to every sphere of life according to Brown (2015, pp.17-18 and 209-210). 
Coupled with the elimination of homo politicus, economisation contaminates the 'lexical and semiotic register' in which democracy operates and, in so doing, it undermines its ability to limit and critique 'capitalist productions of value' (2015, p.208). Democratic articulations come, as a result, under attack and the desire for democracy evaporates. The relevant point that Brown thus makes is that democracy, far from being the culprit in the rise of neoliberal governmentality, it is one of its casualties. Once the conditions congenial to the articulation of its ideals are hollowed out, democracy - and confidence in its transformative potential - is precisely what comes undone (Brown 2015, p.18).

If we therefore follow Brown's account of a democracy undone, we are in a better position to explain why the promissory rule of the many must be read as democratic. The first reason hinges on the valence of the adjective democratic. If Brown is right that the articulation of ideals such as that of equality (universal suffrage, social mobility etc.) is inseparable from democracy and its basic principle of popular rule, then it becomes apparent that abandoning democracy, in favour of some other idea such as communism, is counter-intuitive. There is already a normative force to democracy that other idea(l)s might find difficult to emulate (Olson in Bosteels and Olson, 2016, pp.127-8) and, even if they do, there is little guarantee that these will not be also subject to the same corrosive conditions that undo democracy (Kioupkiolis, 2014).

The second reason, that lends support to a democratic reading of the promise, is closely related. It has to do with the fragility of democracy that Brown does a good job in bringing to our attention. If democracy is neither self-renewing nor self-sustaining, then those radical theories that propose to abandon it only buoy up the expectation that democracy will die out. To countervail it, it is more fruitful to seek to revive democracy by disrupting the conditions that jeopardise its survival. Radical theories that reject democracy in favour of communism, as we saw in the first section, will agree with this suggestion - given that they resuscitate the politics of the many while they find fault with the inequalities that institutional democracy harbours. Along 
similar lines, activists and theorists engaged in the alternative tradition of radical democracy that Conway and Singh (2011) single out, do not altogether dismiss the signifier of democracy, they seek to redescribe it. If, thus, the problem is democracy in its institutional and neoliberal form (that Brown ties with the conditions for democracy), then another kind of democracy, where the many could rule, might still hold sufficient traction for radical theories to allow us to reposition the promissory rule of the many within the democratic frame. This brings me to the third reason that justifies why the promissory rule of the many must be attached to the democratic framework.

Democracy hems in a radical principle. The radical principle in question is the presumption that the people should rule as Brown reminds us (2015, p.207). ${ }^{10}$ When this presumption remains on the horizon it restricts the desire of elites to accrue more privileges (2015, pp.206-208). It functions, therefore, as a threat that hovers over and inevitably limits oligarchic tendencies. The promissory rule of the many envelops this threat as we have already seen. ${ }^{11}$ In this sense, it constitutes a distinctively democratic resource because it is only within the frame of a democracy, that makes room for liberty inasmuch as for equality, that the promissory rule of the many transpires as a threat - as something that can, but does not always, happen. Of course, here it might be objected that theorists and activists concerned with radical practices will resist the scaling-up to the many that the idea of democracy ingrains. They might not resist, however, the threatening dimension of this category that draws attention to the need to displace hegemonic practices. Instead, therefore, of letting this democratic resource be high-jacked by conservative and antidemocratic forces, it is vital that we reappraise and seek to revive it. Radical theories take an important step in this direction when they are reconstructed to align around the promissory politics of the many. In so doing, they bring important benefits to contemporary democratic thought - ones that the next section explores further. 


\section{Radical Democracy Reconstructed: Promissory Politics and Democratic Theory}

So far I have canvased the promissory rule of the many, arguing that this could lay the basis for a reconstructed account of radical democracy. The task of this section is to explain why one should take the trouble to reconstruct the radical democratic account in the first place.

A first answer to this question must be already apparent. Radicalisation through democracy or, in other words, a radical democracy, seems to have run out of steam in the context of gnawing doubts about the transformative potential of democracy in the context of neoliberal hegemony. Notice here that the problem that prompts my enquiry into radical democracy is not that radical theories disagree about the meaning or value of democracy. It is, rather, that they disagree about the continuing usefulness of democracy as a vector of transformation and that this is a serious enough disagreement to licence the need to re-examine, and not simply to defend, radical democracy. The literature has done a good job in defending the term against what Jonathan Dean (2015) aptly captures as the rise of a self-styled 'authentically radical' left emboldened by communism. But it has done little work in studying how and why the terms of the radical democratic kinship might change - to reassert the distinctive contribution of radical democrats within democratic thought.

This reassertion, it is worth noting, comes with particular benefits for theorists and activists concerned with radical practices. If Conway and Singh (2011, p.703) are correct to suggest that the perspectives that saturate such practices do not yet form 'a coherent theoretical project', then it is perhaps relevant to begin to read the reconstruction of radical democracy that I offer here as an attempt to create such a theoretical project. This is, to my mind, necessary if one is to study the perspectives of such practices and the ways they influence the theories of radical democracy. It is also necessary in order to gather together and appreciate these practices as something more than local endeavours. 
The second reason for reconstructing radical democracy is that there is still sufficient common ground in sight to allow this reconstruction. As previous sections showed, radical theories might fervently disagree about the need for democracy, institutional or otherwise, but they strongly converge in the idea that the deprived many - the excluded, exploited or disempowered - hold significant part in transformative politics. Understood as a non-identity, the many subjectify to reinscribe equality and transform the current order. No doubt, the nature of this transformation, which resides in the idea that the many can rule (archein), remains promissory. While the promise does little to assure that such rule is actualised or even deferred; it has a noteworthy effect nevertheless. It restricts anti-democratic forces and it limits oligarchic tendencies. Read, therefore, as possibility in the now, the promise conjoins a threat - that arises at a register other than institutions (namely, the threat of the many) - with a democracy that confines in institutions and is, by inference, affected by such threat. The purpose of this reading is that it makes it possible to reposition the promissory rule of the many within democracy without either underplaying the distrust of liberal hegemonies and institutions that one finds in radical theories or overplaying it by altogether abandoning the signifier of democracy. Its benefit is that it allows the setting up of a contrast with democratic theory - encumbered by the assumption that institutions (elections parliaments and laws) renew and, inevitably, transform the democratic process.

Democratic theory has many voices and there are, to be sure, many ways to read these voices. ${ }^{12}$ But if we narrow down our investigation to the question of popular rule, probing the place that democratic theory gives to this principle, then we can begin to grapple with the difficulties that the term democratic theory presents. For there is, surprisingly, little talk of popular rule among democratic theorists. This hiatus, if it must be seen as such, helps to limit my query, but it does more than this. It lays the basis for the argument that radical democrats contribute to democratic theory precisely through their exploration, and as we have already seen, reworking of the principle of popular rule (as the promissory politics of the many). Therefore, the third reason for reconstructing radical democracy is that it strikes in a different direction from a 
democratic theory that brackets the people on the assumption that, as citizens, they already rule in contemporary democracy.

To say that democratic theorists assume that citizens already rule in a democracy is not a moot theoretical point. When we consider that the question lodged at the heart of such work is how the people rule - not whether they rule; it becomes apparent that this argument only makes explicit the selfevident point that so long as citizens vote and engage in civil society they have ample opportunities to experience self-rule. If we take this point further, it also becomes apparent that radical democrats propose something else. Dissatisfied with the ways that contemporary democracies only tend to the wealthy few, they propose to bring the many back into politics not simply to extend democracy to ever new domains. The many, it must be recalled, could rule according to radical democrats - precisely because they do not rule. None of the standard theories, which the democratic canon divides into, will readily agree with this proposition. For example, pluralist theories concerned with the ways in which citizens influence and limit the democratic process focus on the competitions and contests that safeguard pluralist democracies (Dahl, 1971; Held, 2006). They do not ponder the ebb and flow of popular rule, because they assume that citizens find ways to channel their plural interests into the democratic process.

Deliberative theories that are more attuned to questions of exclusion, apathy and empowerment look likewise mostly to institutionalised processes. They seek to expand and enhance the legitimating mechanisms of contemporary democracies, by developing procedural blueprints that boost citizen input into the governmental process (Fishkin,1991). They are not worried that the people do not rule because deliberative processes ensure that citizens have various fora at their disposal to form and express their preferences of the political process. Along similar lines, elitist theories focus on the institutional process and the ways in which the electorate authorises and controls the politicians who act on its behalf (Green, 2010; Held, 2006). The people neither exists for such theories nor can, for that matter, rule - only voters and spectators rule, if by rule we understand exerting some control over the 
decision making process. In sum, the point of this stylised caricature is to show that democratic theory offers good grounds for the claim that citizens already rule in the democratic process. Whether these citizens are depicted as its voters or critics, they are the bedrock of democracy. The people are not and this is what I think is part of the problem.

Of course, the category of the people is not the same as the category of the many that I made the case for in the previous section. The many do not have the single will of the people even though they likewise arise in a subjectifying process. At the same time, the category of the many cannot be reduced to the citizens of liberal democracy. The many is a non-identity, a kind of deprived existence, one that is at odds with the positive identity of the citizens. Nevertheless, the many carries some of the legality that is distinctive of citizenship - or at least it does not rule out this legality as it finds expression in the rights of voting and protesting. And also, crucially for the next step in my argument, the category of the many carries the connotations of ordinariness and equality that attach to the category of the people - that should rule in democracy (Brown, 2015).

Democratic theorists, no doubt, suspect the people when this overlaps with the many. As David Held aptly explains, the rule of the many means on this line of thinking 'the pursuit of unbridled desires and interests on the one hand, and ignorant short sighted views on the other' (2006, p. 231). This leads some democratic theorists to negate the many (Green, 2010). It leads others to look to enlighten them. ${ }^{13}$ Their marginalisation, coupled with an unbridled confidence in institutions, leaves democratic theory with little resources to grapple with growing disaffect for democracy. Grounded on a deep seated mistrust of a democracy that fails to deliver for the many, popular disaffect finds expression in elections where candidates styled as anti-establishment emerge triumphant; in referenda that foreground the end of politics as usual; and in various protests. It ensnares a dissatisfaction with the institutional process that is difficult to overlook (Sitrin and Azzellini, 2014). Empirical studies lend support to such dissatisfaction. Gilens and Page (2014) demonstrate, for example, that decision makers rarely take heed of popular 
preferences, promoting most of the time policies that are supported by corporations and the wealthy.

If we take such evidence seriously then we are in better position to understand why democratic theory fails to fathom mounting disaffect for institutional democracy: it undermines the degree to which institutions consolidate unequal democracy. This is not to say that democratic theorists do not worry about political crises or limits inherent to the institutional process, only that they are less convincing when they propose that disaffect springs from disempowerment that has roots in poor institutional performance (Della Porta, 2013). Poor institutional performance might threaten the kind of empowerment that democratic theorists propose will relieve institutional mistrust, but aspirations for empowerment are not the same as the aspirations for equality that seem to fuel this mistrust - especially if we tie equality with the emancipatory politics of the many. In sum, the point I want to make here is that without attention to the many it is difficult to understand the politics of rejection and the mounting disaffect that such politics harbours. Radical democrats can help us to grapple with this disaffect for they tap into the very unease about the way that institutional democracy relates to the many.

One final, crucial, question remains however: Does the promissory rule of the many, which serves as the basis for my reconstruction of radical democracy, bracket the hard question of institutions that a genuine rethinking of radical democracy should involve? After all, it can be argued that an effort to construct radical democratic institutions is what might more effectively strengthen the dialogue with democratic theory. No doubt, democratic theorists (and here I include radical democrats) will see some truth to this argument but at the cost of overlooking the distinctiveness of radical democratic voices - a distinctiveness that lies, as we have seen, in the emphasis that radical democrats place on processes of emptying through practices that ensure openness and participation. If this distinctiveness is seen as a resource for contemporary democratic theorists, as I have argued throughout this section, then aspirations to create radical democratic institutions transpire as misplaced. They bend radical accounts of democracy 
to the vernacular of democratic theory when it might be more fruitful for political life to awaken democratic theorists to the distinctiveness of radical democracy. This distinctiveness, that the present paper pushes further with the idea of the promissory rule of the many, keeps alive the critical attention to institutional democracy without confining democracy to liberal institutions, which we saw theorists and activists expressing concern over at the start of the article. It also keeps alive the need to develop ideational insights into democracy that are significant for those who struggle for another, more egalitarian, democracy. In other words, it keeps alive the need for a promissory politics that assures that the promise that the many will rule becomes less important than the threat that they can rule.

\section{Conclusion}

The aim of this paper has been to put radical democracy under critical scrutiny. Trading on the intuition that the doubts on the transformative potential of democracy - the common article of faith among radical democrats - are threatening to undermine it as a debate in democratic thought; this paper set out to reconstruct it around some other common denominator. While this reconstruction did not yield a new model of radical democracy (it did not aim to), it recast its contribution to democratic theory, by bringing into sharp relief the promissory rule of the many. Without the promise of the many or, in other words, without the promise of a democratic radicalism, Wendy Brown is right that democracy comes to be undone.

Democratic theorists should be no less troubled by this possibility than radical democrats already are.

\section{Endnotes}

${ }^{1}$ For example, Tønder and Thomassen explain how the critical emphasis that radical democrats place on openness issues from the ontological claim that a 'radical difference' will always dissect and subvert orders that are considered to be fixed, consensual or universal $(2005$, p.1). If a 'radical difference' is constitutive of socio-political being, then no relation of exclusion remains unquestioned for long. It becomes the subject of contestation, revision and reform. This ethos of contestation is what some theorists take to be the 
defining marker of radical democracy (Howarth, 2008; Glynos, 2003). Radical democracy usually melds with agonism on this line of thought.

2 Aletta Norval, for example, distinguishes between a post-structuralist and a critical theory strand of radical democracy and she suggests that, while they disagree on how to radicalise democracy (consensually or agonistically), they strongly agree on the need to expand the domains in which democratic participation may be exercised (Norval, 2001).

3 This is not surprising. For the post-1968 left it made little sense to question whether the extension and deepening of a participatory democracy would make a difference to society. If such questions were raised at all, they were tied to particular ontologies whose differences were in turn used to explain the ensuing disagreements on the type of democracy that was radicalized.

${ }^{4}$ Boaventura de Souza Santos uses the term 'epistemologies of the South' to capture 'the perspective of those who have systematically suffered the dominations caused by colonialism and capitalism' (2016, p.18). While Walter Mignolo stresses, in a step further, the need to develop 'border thinking' epistemologies that rooted in subaltern practices offer alternative accounts that displace hegemonic significations (2000, p.742).

${ }^{5}$ See Jonathan Dean, 2015.

6 While Hardt and Negri (2009) stress the productive dimension of immaterial labour; Žižek

(2011) and Dean (2016) expound a capitalist order that is only subjecting and totalising.

${ }^{7}$ For example, Alain Badiou (2013), Ernesto Laclau (2005) and Jodi Dean (2016) all use the term people. However, Badiou distinguishes the inexistent from the citizens of state democracy (2012); Dean distinguishes it from the crowd (2016); and Laclau (2005) ties its rise with the dynamics of representation that Badiou takes issue with. To make matters more complicated, Hardt and Negri (2009) speak of the multitude or more recently the commoners (2012); and Žižek usually uses the term 'excluded' (2010 \& 2011) or he follows Jacques Rancière's account of the have-nots (1999). It can thus be readily seen that the category of the many, which cuts across this variation, can have a productive bearing on the analysis of the commonalities among radical theories - in a way that the concept of the people, which it comes close to, does not.

8 For an explanation of archein see Ober, 2008. My account differs from his in that archein is already implicit in (and not opposed to) kratein.

${ }^{9}$ Here I assume that for Deleuzean influenced theorists eventualization and actualisation go hand-in-hand. But one cannot fail to notice, in this context, that references to actualisation also permeate the promise of eventuality that one finds in the work of Badiou (2012) and Bosteels (2011a).

${ }^{10}$ A clarification is due at this point. Whereas Brown proposes that the people should rule, I propose that for theories that are concerned with radical emancipatory projects the many could rule. Even though Brown does not explicitly confront this second possibility, she circles around it when she dissects the elimination of homo politicus. At the same time, it is worth noting that while Brown speaks of the 'bare promise of bare democracy' - by which she understands the idea that the people should rule (2015, p.203) - she does not see this promise either as radical or threatening, which is how I 
effectively approach these to explain why the promissory rule of the many must be seen as democratic.

11 It is important to stress that from my perspective the threat attaches to the promise - not to the presumption of popular rule that Brown speaks about.

12 For example, Urbinati and Warren (2008) distinguish between theories that work within standard accounts of representative democracy and those that focus on participation. David Held (2006) distinguishes between elitist, pluralist and deliberative theories of democracy.

${ }^{13}$ See Urbinati's critique of deliberative democracy as one form of epistemocracy (2014, pp.81-127).

\section{References}

Badiou, A. (2013) Our Contemporary Impotence. Radical Philosophy 181:4347.

Badiou, A. (2012) The Rebirth of History. London and New York: Verso.

Badiou, A. (2010) The Idea of Communism. In: C. Douzinas and S. Žižek (eds) The Idea of Communism. London and New York: Verso, pp.1-14.

Bosteels, B. and Olson, K. (eds) (2016) What is a People?. New York: Columbia University Press.

Bosteels, B. (2011a) The Actuality of Communism. London and New York: Verso.

Bosteels, B. (2011b) Badiou and Politics. Durham and London: Duke University Press.

Brown, W. (2015) Undoing the Demos. New York: Zone Books.

Chambers, S.A. (2004) Giving up (on) Rights? The Future of Rights and the Project of Radical Democracy. American Journal of Political Science 48(2): 185- 200.

Connolly, W. (2017) Entangled Humanism and the Politics of Swarming. Durham and London: Duke University Press.

Conway, J. and Singh, J. (2011) Radical Democracy in Global Perspective: Notes from the Pluriverse. Third World Quarterly 32(4): 689-706.

Dahl, R.A. (1971) Polyarchy: Participation and Opposition. New Haven: Yale University Press.

Dean, Jodi (2016) Crowds and Party. London and New York: Verso.

Dean, Jodi (2012) The Communist Horizon. London and New York: Verso.

Dean, Jonathan (2015) Radicalism Restored? Communism and the End of Left Melancholia. Contemporary Political Theory 14(3): 234-255.

De Souza Santos, B. (2016) Epistemologies of the South and the Future. From the European South 1:17-29.

Della Porta, D. (2013) Can Democracy Be Saved?. Cambridge: Polity Press.

Derrida, J. (2006) Specters of Marx. New York and London: Routledge.

Estlund, D. (2008) Democratic Authority: A Philosophical Framework. Princeton, NJ: Princeton University Press.

Fishkin, J. (1991) Democracy and Deliberation. New Haven: Yale University Press.

Fritsch, M. (2002) Derrida's Democracy To Come. Constellations 9(4): 574597. 
Gilens, M. and Page, B.I. (2014) Testing Theories of American Politics: Elites, Interest Groups and Average Citizens. Perspectives on Politics 12(3): 564-581.

Glynos, J. (2003) Radical Democratic Ethos, or, What is an Authentic Political Act?. Contemporary Political Theory 2:187-208.

Green, J. E.(2010) The Eyes of the People. Oxford and New York: Oxford University Press.

Hardt, M. and Negri, A. (2017) Assembly. Oxford and New York: Oxford University Press.

Hardt, M. and Negri, A. (2012) Declaration. New York: Argo Navis Author Services.

Hardt, M. and Negri, A. (2009) Commonwealth. Cambridge, MA: Harvard University Press.

Held, David (2006) Models of Democracy. Cambridge: Polity Press.

Howarth, D. (2008) Ethos, Agonism and Populism: William Connolly and the Case for Radical Democracy. British Journal of Politics and International Relations 10(2): 171-193.

Kioupkiolis, A. (2018) Movements Post-hegemony: How Contemporary Collective Action Transforms Hegemonic Politics. Social Movement Studies 17(1): 99-112.

Kioupkiolis, A. and Katsambekis, G. (eds) (2014) Radical Democracy and Collective Movements Today. London and New York: Routledge.

Kioupkiolis, A. (2011) Keeping It Open: Ontology, Ethics, Knowledge and Radical Democracy. Philosophy and Social Criticism 37(6): 691-708.

Laclau, E. and Mouffe, C. (2001) Hegemony and Socialist Strategy. London and New York: Verso.

Laclau, E. (2005) On Populist Reason. London and New York: Verso.

Landemore, $\mathrm{H}$. (2012) Why the Many Are Smarter than the Few and Why it Matters. Journal of Public Deliberation 8(1): 1-12.

Little, A. and Lloyd, M. (2009) The Politics of Radical Democracy. Edinburgh: Edinburgh University Press.

Marchart, O. (2007) Post-Foundational Political Thought. Edinburgh: Edinburgh University Press.

McClure, K. (1992) On the Subject of Rights: Pluralism, Plurality and Political Identity. In: C. Mouffe (ed.) Dimensions of Radical Democracy. London: Verso, pp.108-127.

Mignolo, W. (2009) Epistemic Disobedience, Independent Thought and Decolonial Freedom. Theory Culture and Society 26(7-8): 159-181.

Mignolo, W. (2000) The Many Faces of Cosmo-polis: Border Thinking and Critical Cosmopolitanism. Public Culture 12 (3):721-748.

Mouffe, C. (2018) For a Left Populism. London: Verso.

Norval, A. (2001) Radical Democracy. In: P.B. Clarke and J. Foweraker (eds) Encyclopedia of Democratic Thought. Abingdon and New York: Routledge, pp.587-594.

Ober, J. (2008) The Original Meaning of 'Democracy': Capacity to Do Things, Not Majority Rule. Constellations 15(1): 1-9.

Prentoulis, M. and Thomassen, L. (2013) Political Theory in the Square: Protest, Representation and Subjectification. Contemporary Political Theory 12(3): 166-184. 
Rancière, J. (2011) Staging the People: The Proletarian and His Double. London and New York: Verso.

Rancière, J. (1999) Disagreement. Minneapolis, MN: University of Minnesota Press.

Sitrin, M. and Azzellini, D. (2014) They Can't Represent Us. London and New York: Verso.

Thomassen, L. (2007) Beyond Representation?. Parliamentary Affairs 60(1): 111-126.

Tønder, L. and Thomassen, L. (eds) (2005) Radical Democracy: Politics Between Abundance and Lack. Manchester and New York: Manchester University Press.

Tormey, S. (2015) The End of Representative Politics. Cambridge: Polity Press.

Trend, D. (1996) Radical Democracy: Identity, Citizenship and the State. New York: Routledge.

Tully, J. (2014) On Global Citizenship. London and New York: Bloomsbury Academic.

Urbinati, N. (2014) Democracy Disfigured: Opinion, Truth and the People. Cambridge, MA: Harvard University Press.

Urbinati, N. \& Warren, M.E. (2008) The Concept of Representation in Contemporary Democratic Theory. Annual Review of Political Science 11:387- 412.

Woodford, C. (2017) Disorienting Democracy. Abingdon and New York: Routledge.

Žižek, S. (2010) How to Begin from the Beginning. In: C. Douzinas and S. Žižek (eds) The Idea of Communism. London and New York: Verso, pp. 209-226.

Žižek, S. (2011) Living In the End Times. London and New York: Verso. 